Acta Crystallographica Section E

\section{Structure Reports}

Online

ISSN 1600-5368

\section{Frank H. Herbstein ${ }^{\mathrm{a} *}$ and Shengzhi $\mathbf{H u}^{\mathrm{b}}$}

${ }^{\text {a }}$ Schulich Faculty of Chemistry, Technion-Israe Institute of Technology, Haifa, Israel 32000, and ${ }^{\mathbf{b}}$ Department of Chemistry, Xiamen University,

Xiamen, People's Republic of China

Correspondence e-mail:

chr03fh@tx.technion.ac.il

\title{
On the polymorphism of thiamine dichloride monohydrate (Vitamin B1)
}

To date the structures of only two polymorphs of thiamine dichloride monohydrate have been reported in the literature.

\section{Comment}

The crystal structure of a new polymorph of Vitamin B1 has recently been described (Balasubramanian et al., 2006). According to these authors, this is the third polymorphic form of this important biochemical to be identified and they note that 'two different forms [were] reported previously' by Kraut \& Reed (1962) and Suh et al. (1982); similar statements appear in their Abstract and elsewhere in their text. These statements about the number of polymorphs require careful examination. The reported cell dimensions summarized in Table 1 clearly fall into two groups - firstly Cambridge Structural Database (CSD, Version 1.8; Allen et al., 2002) refcodes THIAMC, THIAMC01 and THIAMC12, and then separately polymorph III (THIAMC13). In the first group, the values of $a, b$ (unique) and unit-cell volume are very similar but the values of $\beta$ and $c$ differ, as do the assigned space groups. One immediately suspects that revised choices of $\beta$ and $c$ would give essentially the same unit cells and the same space group for all three members of the first group. This has been confirmed by transforming THIAMC12 to space group $P 2_{1} / c$, as shown in Table 1. An alternative but equivalent method of demonstrating the equivalence of the group I structures is via the reduced cells, not reproduced here but given in the CSD. Suh et al. (1982, see p. 116) recognized that they and Kraut \& Reed studied the same polymorph. For convenience, we designate the group I structure as the $P 2_{1} / n$ polymorph and the THIAMC13 structure as the $P 2_{1} / c$ polymorph; standard designations require knowledge of the thermodynamic relations between the polymorphs.

We note that the differences in cell dimensions for the various independent determinations are far larger than their
Received 21 October 2006 Accepted 9 March 2007

Table 1

Cell dimensions reported for Vitamin $\mathrm{B} 1\left(\AA{ }^{\circ},{ }^{\circ}, \AA^{3}\right)$.

Measurements at nominal $300 \mathrm{~K}$ unless stated otherwise. Standard uncertainties as in publications; those of III were measured 'from 25 reflections'.

\begin{tabular}{|c|c|c|c|c|c|c|c|c|}
\hline Refcode & $\begin{array}{l}\text { Polymorph } \\
\text { designation }\end{array}$ & $a$ & $b / \beta$ & $c$ & $\begin{array}{l}\text { Unit cell } \\
\text { volume }\end{array}$ & $\mathrm{Z}$ & $\begin{array}{l}\text { Reported } \\
\text { space } \\
\text { group }\end{array}$ & Reference \\
\hline \multicolumn{9}{|l|}{ Group I results } \\
\hline THIAMC & I & $6.99(1)$ & 20.59 (2) $114.0(1)$ & $12.73(2)$ & 1673.8 & 4 & $P 2_{1} / c$ & Kraut \& Reed (1962) \\
\hline THIAMC01† & II & 6.975 & 20.55598 .78 & 11.727 & 1661.16 & 4 & $P 2_{1} / n$ & Suh et al. (1982) \\
\hline THIAMC12 296K & Not given & $6.9928(2)$ & 20.6631 (10) 98.699 (2) & $11.7695(5)$ & $1681.0(2)$ & 4 & $P 2_{1} / n$ & Te et al. (2003) \\
\hline $\begin{array}{l}\text { THIAMC12 reoriented to } P 2_{1} / c \\
\text { Group II results }\end{array}$ & & 6.9928 & 20.6631114 .369 & 12.775 & 1681.0 & 4 & $P 2_{1} / c$ & \\
\hline THIAMC13 $173 \mathrm{~K}$ & III & $9.1437(2)$ & 7.3438 (2) $92.112(1)$ & $24.7447(6)$ & $1660.47(7)$ & 4 & $P 2_{1} / c$ & Balsubramanian et al. (2006) \\
\hline
\end{tabular}

$\dagger$ Also given as THIAMC11 (Suh \& Kim, 1982) 
Table 2

Some torsion angles $\left(^{\circ}\right)$ calculated from the published atomic coordinates.

The nomenclature follows that of Balsubramanian et al. (2006). Standard uncertainties are about $0.1^{\circ}$. As the molecules are chiral (although the crystals are racemic) it is necessary to specify the enantiomer when making comparisons; all our values refer to the enantiomer with $\phi \mathrm{D} \approx 79^{\circ}$. There are some differences of sign between our values and those of Balsubramanian et al. (2006), presumably due to different choices of enantiomer.

\begin{tabular}{|c|c|c|c|c|c|}
\hline Refcode & $\phi \mathrm{T} \tau(\mathrm{C} 2-\mathrm{N} 1-\mathrm{C} 7-\mathrm{C} 8)$ & $\phi \mathrm{D} \tau(\mathrm{N} 1-\mathrm{C} 7-\mathrm{C} 8-\mathrm{C} 9)$ & $\phi \mathrm{S} \alpha \tau(\mathrm{S} 1-\mathrm{C} 1-\mathrm{C} 4-\mathrm{C} 5)$ & $\phi \mathrm{S} \beta \tau(\mathrm{C} 1-\mathrm{C} 4-\mathrm{C} 5-\mathrm{O} 1)$ & $\tau(\mathrm{C} 7-\mathrm{C} 8-\mathrm{C} 9-\mathrm{N} 2)$ \\
\hline THIAMC & 170.8 & 76.1 & 103.4 & 53.8 & 176.8 \\
\hline THIAMC01 & 170.6 & 74.8 & 100.8 & 50.6 & 177.2 \\
\hline THIAMC12 & 170.9 & 75.7 & 103.1 & 53.6 & 3.5 \\
\hline THIAMC13 & 179.2 & 79.3 & 24.2 & 63.4 & 176.4 \\
\hline
\end{tabular}

reported standard uncertainties, suggesting unspecified systematic differences; dehydration (Te et al., 2003) does not appear to provide an explanation. Comparison of torsion angles (Table 2) provides some more information; it is not clear whether the differences in torsion angles for the three examples of group I are due to real structural differences. Te et al. (2003) describe the $P 2_{1} / n$ polymorph as 'a nonstoichiometric solvate, a class of solvates where the water molecules occupy voids in a stable network that does not collapse after dehydration.'

\section{References}

Allen, F. H. (2002). Acta Cryst. B58, 380-388.

Balasubramanian, T., Jebas, S. R., Thamotharan, S., Rheinwald, G. \& Lang, A. G. (2006). Acta Cryst. E62, o290-o292.

Kraut, J. \& Reed, H. J. (1962). Acta Cryst. 15, 747-757.

Suh, I.-H. \& Kim, Y.-I. (1982). Rep. R. I. Chem. Spect. Chungnam, 3, 3645.

Suh, I.-H., Kim, Y.-I., Yoon, M. J., Ku, Y. \& Ahn, S. T. (1982). J. Korean Phys. Soc. 15, 114-121.

Te, R. L., Griesser, U. J., Morris, K. B., Byrn, S. R. \& Stowell, J. G. (2003). Cryst. Growth Design, 3, 997-1004. 